\title{
DOS DISCURSOS DO PAPA FRANCISCO À PRODUÇÃO E CIRCULAÇÃO DE PEQUENAS FRASES: A CONSTRUÇÃO DO PAPA HETERODOXO
}

\author{
Marilena Inácio de Souza* \\ Universidade do Estado de Mato Grosso/ CNPq \\ Faculdade de Letras, Ciências Sociais e Tecnológicas \\ Curso de Letras \\ Alto Araguaia, MT, Brasil
}

\begin{abstract}
Resumo: O desenvolvimento recente de uma configuração midiática totalmente nova, que associa diretamente a mídia impressa, o rádio, a televisão e a internet, permitiu aumentar significativamente o destacamento e a circulação de pequenas frases. Na tentativa de compreender o funcionamento linguístico e discursivo desse fenômeno, analisamos um conjunto de enunciados extraídos dos discursos do papa Francisco e destacados na mídia. A meta é verificar em que medida o trabalho hermenêutico do enunciador interfere na interpretação do texto citado, fornecendo ao leitor uma espécie de percurso interpretativo. Para isso, mobilizamos vários conceitos da Análise do Discurso francesa - especialmente os conceitos de destacabilidade, sobreasseveração $e$ aforização, desenvolvidos por Maingueneau (2006; 2010; 2014). A análise empreendida autoriza a dizer que os enunciados destacados potencializam a (re)produção e circulação de simulacros sobre o discurso do papa. Tem-se, por consequência, a construção da imagem de um papa heterodoxo.
\end{abstract}

Palavras-chave: Destacamento midiático. Pequena frase. Efeito de sentido.

\section{REFLEXÕES PRELIMINARES}

A circulação de "pequenas frases" descoladas de seus contextos e co-textos originais não é um fenômeno linguístico recente. Desde os tempos imemoriais, elas circulam isoladamente de seus textos-fonte. No entanto, é certamente na contemporaneidade, devido à imediatez com que os fatos são divulgados nas grandes mídias, que elas têm proliferado intensamente. Basta olhar para os mais diversos suportes midiáticos - jornal impresso, jornal online, rádio, televisão, internet, entre outros, para vêlas se manifestando nas manchetes, títulos ou subtítulos de artigos e/ou reportagens.

Maingueneau (2006), ao estudar a presença desses enunciados na mídia francesa, observa que é impossível determinar se eles são assim ("destacáveis") porque os locutores dos textos de origem os quiseram assim, ou se são os jornalistas que os dizem, dessa forma, para legitimar o seu dizer.

\footnotetext{
* Doutora em Linguística - Universidade Federal de São Carlos. Professora da UNEMAT/CNPq. E-mail: marilena-souza@hotmail.com.
} 
De qualquer forma, pelo clássico jogo de antecipação das modalidades de recepção, os produtores dos enunciados, que são profissionais da vida pública, têm tendência a fabricá-los em função dos (re)empregos que deles serão feitos" (MAINGUENEAU, 2006, p. 80).

As "pequenas frases" atestam "a existência de rotinas que consistem em selecionar e distinguir um fragmento de discurso, sem que as regras e as condições deste processo sejam explicadas" (KRIEG-PLANQUE; OLLIVIER-YANIV, 2011, p. 18).

$\mathrm{Na}$ tentativa de compreender esse fenômeno, analisamos um conjunto de enunciados extraídos das declarações do papa Francisco, desde o início de 2013 (quando iniciou o seu pontificado) até os dias atuais, e postos em circulação na mídia. Não se trata de um caso simples de citação, em que os enunciados destacados circulam em outros textos, demarcados por uma sinalização de distanciamento, mas de um trabalho hermenêutico do enunciador. A meta é verificar em que medida esse trabalho interfere na interpretação do texto citado, fornecendo ao leitor uma espécie de percurso interpretativo.

À luz da Análise do Discurso francesa, especialmente dos conceitos de destacabilidade, sobreasseveração e aforização, desenvolvidos por Dominique Maingueneau $(2006 ; 2010 ; 2014)$, buscamos, por um lado, descrever e analisar o funcionamento linguístico e discursivo das "pequenas frases", em estudo; por outro, tornar pertinente a afirmação de que os procedimentos de destaque do discurso do outro, sobretudo, os procedimentos de "destextualização" e de "sobreasseveração" (MAINGUENEAU, 2014) potencializam a (re)produção e circulação de "simulacros" sobre o discurso do pontífice, na esfera midiática, sobretudo, ao se tratar de temas polêmicos para a Igreja Católica.

\section{SOBRE A CONSTITUIÇÃO DO CORPUS E CRITÉRIOS DE SELEÇÃO: UMA QUESTÃO PERTINENTE}

A definição de um corpus de pesquisa supõe necessariamente um recorte, o que deixa de fora, inevitavelmente, uma série de fenômenos. Neste estudo não é diferente: o recorte é o resultado de uma construção teórica, isto é, um trabalho de pesquisa e interpretação que exige, por definição, a exclusão de muitos elementos. Os enunciados selecionados para análise são, assim, o resultado de recortes e exclusões que, por um lado, põe em evidência o fenômeno das "pequenas frases". Por outro, permite averiguar em que medida esse fenômeno interfere na produção, circulação e interpretação dos acontecimentos enunciativos.

Uma rápida busca no site do Google, por enunciados que teriam sido extraídos dos discursos do papa Francisco, demonstrou que uma variedade muito grande deles circula na mídia, desde sua primeira declaração, em março de 2013, até os dias atuais. Não é novidade o fato de que, basicamente, tudo o que o pontífice fala se torna notícia. Em consequência, um número muito grande de enunciados atribuídos ao papa ganha notoriedade nas principais páginas de jornais, de revistas, de programas de informação televisivos, entre outros. Daí a necessidade de estabelecer alguns critérios de seleção do corpus. 
O primeiro deles diz respeito ao recorte temporal, compreendido entre os anos de 20013 a 2016. Nesse período, o pontífice fez muitas viagens, visitou vários países, rezou muitas missas e, consequentemente, concedeu inúmeras entrevistas. Em seus discursos, abordou os mais variados temas, desde os mais "ordinários" aos que, ainda hoje, são considerados polêmicos para a Igreja, tais como: orientação sexual, aborto, pedofilia, taxa de natalidade, métodos contraceptivos, divórcio, nulidade matrimonial, diálogo interreligioso, etc. Consequentemente, vários enunciados se desprenderam desses discursos e passaram a frequentar outros textos. Interessamo-nos apenas por aqueles que se tornaram objeto de comentários, sendo constantemente retomados e comentados na/pela mídia. Trata-se da circulação de 10 enunciados, organizados na tabela, a seguir, a partir de uma ordem cronológica de circulação:

\section{Quadro 1 - Apresentação do corpus}

\begin{tabular}{|c|c|}
\hline Destacamentos midiáticos & Declarações atribuídas ao papa Francisco \\
\hline $\begin{array}{l}\text { 1- “O carnaval acabou!” diz papa Francisco, ao } \\
\text { recusar a capa usada por Bento } 16 \text {; } \\
\text { (FOLHA Online, } 16 / 03 / 2013 \text { ) }\end{array}$ & $\begin{array}{l}\text { "Não, obrigada monsenhor, você pode vesti-la. O } \\
\text { carnaval acabou." }\end{array}$ \\
\hline $\begin{array}{l}\text { 2- "Homossexuais não devem ser julgados ou } \\
\text { marginalizados", diz papa (G1, 29/07/2013) }\end{array}$ & $\begin{array}{l}\text { "Os gays não devem ser marginalizados, mas } \\
\text { integrados a sociedade. Se uma pessoa é gay, busca } \\
\text { Deus e tem boa vontade, quem sou eu para julgá- } \\
\text { los? O problema não é ter essa orientação. } \\
\text { Devemos ser irmãos. O problema é fazer lobby por } \\
\text { essa orientação, ou lobbies de pessoas invejosas, } \\
\text { lobbies políticos, lobbies maçônicos, tantos } \\
\text { lobbies. Esse é o pior problema." }\end{array}$ \\
\hline $\begin{array}{l}\text { 3- "Não existe um Deus católico, mas um Deus", } \\
\text { diz papa (ESTADÃO, 02/10/2013) }\end{array}$ & $\begin{array}{l}\text { "Não existe um Deus católico, há um Deus. } \\
\text { Religião sem misticismo é apenas filosofia." }\end{array}$ \\
\hline $\begin{array}{l}\text { 4- "Não há fogo no inferno, Adão e Eva não são } \\
\text { reais", diz o papa Francisco } \\
\text { (FOLHA BRASIL, 22/01/2014) }\end{array}$ & $\begin{array}{l}\text { "A igreja já não acredita em um inferno literal, } \\
\text { onde as pessoas sofrem. Esta doutrina é } \\
\text { incompatível com o amor infinito de Deus. Deus } \\
\text { não é um juiz, mas um amigo e um amante da } \\
\text { humanidade. Deus nos procura não para condenar, } \\
\text { mas para abraçar. Como a história de Adão e Eva, } \\
\text { nós vemos o inferno como um artifício } \\
\text { literário. O inferno é só uma metáfora da alma } \\
\text { exilada (ou isolada), que, como todas as almas em } \\
\text { última análise, estão unidos no amor com DEUS." }\end{array}$ \\
\hline $\begin{array}{l}\text { 5- Papa diz que cachorros vão para o céu e cria } \\
\text { polêmica com teólogos (FOLHA Online, } \\
\text { 12/12/2014); }\end{array}$ & "O paraíso está aberto a todas as criaturas." \\
\hline $\begin{array}{l}\text { 6- Católicos não devem procriar "como coelhos", } \\
\text { diz papa } \\
\text { (VEJA, 19/01/2015); }\end{array}$ & $\begin{array}{l}\text { "Algumas pessoas pensam- me desculpem a } \\
\text { expressão aqui- que para ser um bom } \\
\text { católicoprecisam ser como coelhos. Não. } \\
\text { Paternidade tem a ver com responsabilidade. Isto é } \\
\text { claro." }\end{array}$ \\
\hline $\begin{array}{l}\text { 7- Papa: Divorciados que voltam a se casar e } \\
\text { seguem fazendo parte da Igreja não devem ser } \\
\text { tratados como "excomungados" (CORREIO } \\
\text { BRASILIENSE, 05/08/2015) }\end{array}$ & $\begin{array}{l}\text { "É necessária uma fraterna e atenta acolhida, no } \\
\text { amor e na verdade, em direção a estas pessoas que } \\
\text { efetivamente não estão excomungadas, como } \\
\text { alguns pensam: elas formam parte sempre da } \\
\text { Igreja." }\end{array}$ \\
\hline
\end{tabular}

SOUZA, Marilena Inácio de. Dos discursos do papa Francisco à produção e circulação de pequenas frases: a construção do papa heterodoxo. Linguagem em (Dis)curso - LemD, Tubarão, SC, v. 16, n. 3, p. 465-487, set./dez. 2016. 


\begin{tabular}{|l|l|}
\hline $\begin{array}{l}\text { 8- Papa pede que padres perdoem católicas que } \\
\text { praticaram aborto }\end{array}$ (A TRIBUNA, 01/09/2015) & $\begin{array}{l}\text { "Alguns vivem o drama do aborto com uma } \\
\text { consciência superficial, quase sem perceber o } \\
\text { gravíssimo mal que comporta um ato deste tipo. } \\
\text { Muitos outros, porém, inclusive vivem este } \\
\text { momento como uma derrota, consideram não ter } \\
\text { outro caminho por onde ir. O perdão de Deus não } \\
\text { pode ser negado a qualquer um que tenha se } \\
\text { arrependido." }\end{array}$ \\
\hline $\begin{array}{l}\text { 9- Igreja não pode ser "museu de memórias," diz o o } \\
\text { papa em Sínodo } \\
\text { (G1,05/10/2015) }\end{array}$ & $\begin{array}{l}\text { "A Igreja não deve ser um tacanho museu de } \\
\text { memórias, mas precisa ter a coragem de mudar, se } \\
\text { for isso o que Deus quiser." }\end{array}$ \\
\hline $\begin{array}{l}\text { 10- Papa Francisco diz que, diante de Zika, } \\
\text { contracepção é "um mal menor" } \\
\text { (EXTRA, 18/02/2016) }\end{array}$ & $\begin{array}{l}\text { "O aborto não é um mal menor. É um crime. É } \\
\text { descartar um para salvar o outro. Mas evitar a } \\
\text { gravidez é. Paulo VI, em uma situação difícil, na } \\
\text { Africa, permitiu às religiosas o uso de } \\
\text { anticoncepcionais em casos de (iminente) } \\
\text { violência. Não confunda o mal de evitar gravidez, } \\
\text { sozinho, com o aborto." }\end{array}$
\end{tabular}

Fonte: Autora

Os critérios de seleção e organização dos dados foram estabelecidos considerando as práticas sociais e a forma como as "pequenas frases" são produzidas pelos jornalistas e se manifestam na mídia. Assim, esperamos abordar o uso social das "pequenas frases" e, consequentemente, ressaltar a maneira por meio da qual o sentido pode ser "forjado" por certas opções linguístico-discursivas.

\section{DOS DISCURSOS DO PAPA FRANCISCO AO DESTACAMENTO MIDIÁTICO: EFEITOS DA SOBREASSEVERAÇÃO}

Para descrever e analisar o funcionamento linguístico e discursivo dos enunciados tomados como objeto, recorremos à noção de destacabilidade apresentada por Maingueneau em sua obra Cenas da Enunciação (2006). Essa noção diz respeito a um conjunto de propriedades de certas frases que as fazem ser destacadas e circular, eventualmente, fora do texto de origem. Além das máximas, dos provérbios, dos slogans e das divisas - enunciados que, segundo o autor, são por natureza destacados - uma série de outros enunciados pode receber este estatuto, basta que, para isso, se apresentem como enunciados “destacáveis". Isto é, passíveis de serem destacados de um texto, graças à posição em que se encontram, ao sentido de definição ou generalização que lhe pode ser atribuído, à marca de uma operação metadiscursiva, à forma sintética e inusitada. Em outros termos, trata-se

\footnotetext{
de enunciados curtos, cujos significante e significado são considerados no interior de uma organização pregnante (pela prosódia, rimas internas, metáforas, antíteses...), o que explica que sejam facilmente memorizados. Algumas dessas fórmulas circulam no interior de uma comunidade mais ou menos restrita, outras são conhecidas por um grande número de locutores espalhados em vários setores do espaço social. (MAINGUENEAU, 2006, p. 72)
} 
Eles comportam ainda duas características que, a princípio, se apresentam como paradoxais: "são percebidos como inéditos; são percebidos como imemoriais." (MAINGUENEAU, 2006, p. 74).

A destacabilidade abre a possibilidade de uma "destextualização", de uma saída do texto, e, assim, entra em tensão com a dinâmica da textualização, isto é, caminha na direção oposta à de integrar os constituintes do texto em uma unidade orgânica. Não se trata de uma citação, mas de uma enfatização em relação ao entorno textual, de uma operação que Maingueneau (2006) chama de sobreasseveração. Ou seja, ao sobreasseverar um determinado enunciado, o enunciador não realiza uma citação, mas apenas uma operação de destaque do trecho em relação ao restante dos enunciados que constituem o tecido textual, por meio de marcadores diversos: de ordem aspectual (genericidade), tipográfica (posição de destaque dentro de uma unidade textual), prosódica (insistência), sintática (construção de uma forma pregnante), semântica (recurso aos tropos), lexical (utilização de conectores de reformulação).

Por definição, sobreasseverar é antecipar um destacamento. Dessa forma, a sobreasseveração se aplica a todas as situações em que uma sequência breve se sobressai em um texto. Geralmente, as sequências sobreasseveradas já se encontram em posição de destaque no texto, possuem um caráter generalizante; são uma tomada de posição no campo discursivo e implicam amplificação da figura do enunciador. A imprensa escrita explora a sobreasseveração de diversas formas. A mais clássica delas, segundo Maingueneau (2006), aparece geralmente na forma de "pequenas frases", colocadas em destaque nos títulos e subtítulos de manchetes e/ou reportagens, como as apresentadas na tabela de elucidação do corpus e retomadas, neste tópico, para efeito de análise.

Os enunciados sobreasseverados na imprensa não se constituem sempre da mesma forma. Dois tipos de destacamento, segundo Maingueneau (2006), são responsáveis por sua produção e circulação: o "destacamento fraco", em que o enunciado destacado permanece vizinho do texto de origem, sem, no entanto, implicar uma total fidelidade; e o "destacamento forte", em que o enunciado destacado rompe com o texto de origem. Nos dois casos, a sobreasseveração implica uma figura de enunciador que não apenas diz, mas que mostra o que diz e presume-se que o que ele diz condensa uma mensagem forte, induz a uma tomada de posição.

Assim, a sobreasseveração produz um efeito de evidência no enunciado: por um lado, apresenta-se como sendo algo incontestável e, por outro, orienta o leitor para a construção de novos sentidos. No caso em estudo, conforme demonstra a análise a seguir, essa orientação caminha no sentido de construir, para o pontífice, a imagem de um papa inovador e heterodoxo. No entanto, a sobreasseveração desresponsabiliza o jornalista dessa orientação. A responsabilidade dos enunciados destacados recai sempre sobre o sobreasseverador.

\footnotetext{
O sobreasseverador é alguém que se sobrepõe, que mostra o ethos de homem autorizado, sob a influência de uma "Origem transcendente", que estabelece valores, para além das interações e das argumentações. O apagamento da relação com o co-texto acompanha um reforço do engajamento ilocutório. (MAINGUENEAU, 2006, p. 89)
} 
O sobreasseverador é mais o efeito da sobreasseveração, o correlato do enunciado, do que sua fonte. Isso implica dizer que os locutores-origem se encontram, dessa forma, na posição de sobreasseveradores de enunciados que nem sempre foram formulados como tais nos textos. Produz-se um desacordo essencial entre o locutor efetivo e esse mesmo locutor considerado como sobreasseverador de um enunciado que foi destacado pela mídia. No entanto, a sobreasseveração legitima o enunciado destacado, pela evocação da autoridade do discurso de outro, nesse caso, o discurso do papa Francisco

O excerto a seguir, publicado no jornal da Folha online, em 16 de março de 2013, é um bom exemplo do que Maingueneau (2006) chama de "destacamento forte":

\section{Figura 1 - Reportagem 1}

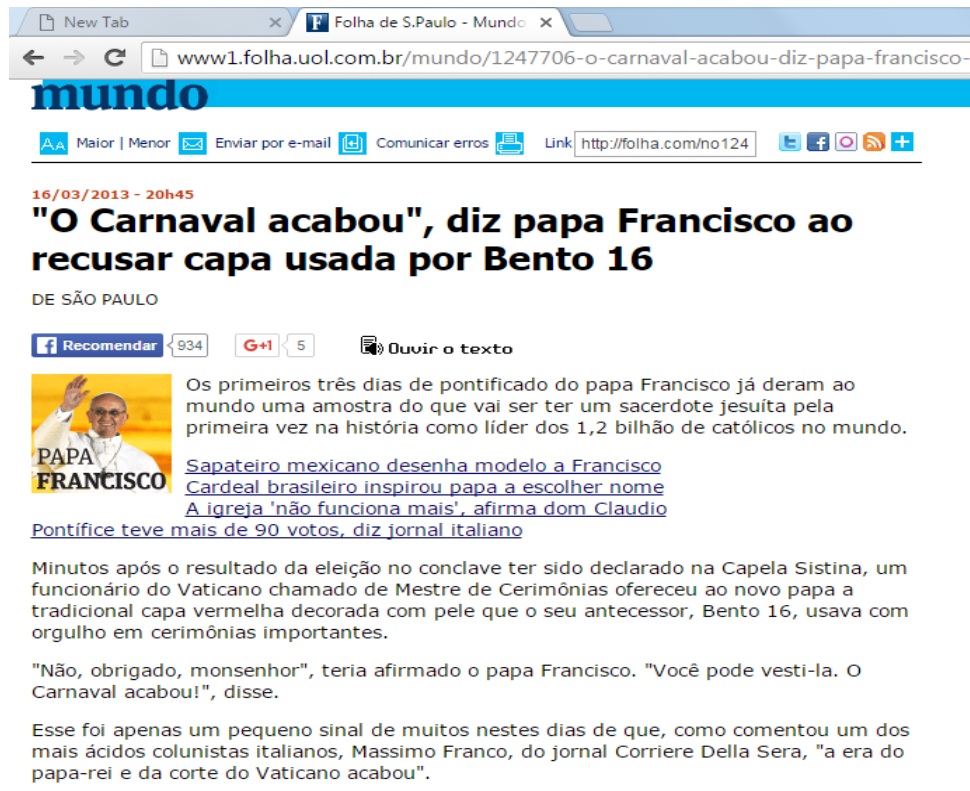

Fonte: Site <www.folha.uol.com.br>, em 16/03/2013.

Ao comparar o enunciado destacado no topo do jornal à enunciação original, observamos que não é exatamente a frase proferida pelo papa Francisco que o enunciador destaca. Segundo o jornalista, o pontífice disse: "O carnaval acabou”, ao recusar a capa usada por Bento 16. Por sua vez, o pontífice teria dito: "Não, obrigada monsenhor, você pode vesti-la. O carnaval acabou." Desse fragmento, o jornalista destaca apenas alguns elementos linguísticos, colocando-os em evidência no título da reportagem. Dentre as frases inscritas no co-texto original, destextualiza-se um único enunciado, que é colocado em posição de relevo em relação ao restante do texto. A declaração do pontífice é modalizada pelo jornalista, passando simplesmente ao enunciado "O carnaval acabou." E esse enunciado passa a significar metonimicamente o acontecimento enunciativo em destaque.

Para compreender a singularidade desse acontecimento, é necessário retomar as condições de produção em que a frase atribuída ao Papa Francisco teria sido pronunciada. Segundo o site italiano Mesa in Latino, antes da aparição pública para os fiéis, após sua eleição, o sumo pontífice dirigiu-se à sacristia, na qual o cerimoniário papal, Monsenhor 
Guido Marini, havia preparado os hábitos pontificais, desde sempre utilizados pelos papas. Diante das vestes, o papa teria dito ao cerimoniário: "Não, obrigado monsenhor, você pode vesti-la. O carnaval acabou." Posteriormente, então, o papa, recém-eleito, apareceu ao público apenas com a batina branca, com seu crucifixo de aço (sem substituílo pelo de ouro) e sem a tradicional capa vermelha, chamada de mozzeta.

O enunciado destacado "O carnaval acabou" (re)ssignifica esse acontecimento. Não se trata somente de divulgar o acontecimento que marcou a primeira aparição do sumo pontífice, com destaque para as suas vestes pontificais, mas, sobretudo, de atualizálo, levando o leitor à interpretação de que, no pontificado do papa Francisco, os paramentos litúrgicos serão marcados pela simplicidade, sem excessos ou extravagâncias. O conteúdo do enunciado em questão é, ao mesmo tempo, perfeitamente transparente e profundamente opaco.

A opacidade do enunciado tem a ver tanto com a carga semântica do vocábulo "carnaval" quanto com os discursos que sua enunciação recupera. De acordo com o dicionário Aurélio, a palavra "carnaval” é um substantivo masculino, que indica o período anual de festas profanas, originadas na Antiguidade e recuperadas pelo cristianismo. Começa no dia de Reis e acaba na Quarta Feira de Cinzas, às vésperas da Quaresma. No senso comum, o "carnaval" representa a maior festa popular brasileira, que se caracteriza por suas extravagantes fantasias e adereços carnavalescos. Trata-se de uma festa que promove desfiles luxuosos de escolas de samba e arrebata multidões para as ruas. Os foliões extravasam suas emoções e suas paixões carnais, promovendo "comilanças", extravagancias, sensualidade, erotismo, exibicionismo e culto ao corpo. A Igreja, comumente, usa essa palavra para se referir à "festa da carne".

Dessa forma, o enunciado "O carnaval acabou" é profundamente opaco: sua materialidade léxico-sintática (um substantivo simples na posição de sujeito, a marca temporal do lexema verbal "acabou", indicando o fim do "carnaval" (neste caso, uma metáfora), a ausência de complementos) imerge esse enunciado em uma rede de relações associativas implícitas - paráfrases, implicações, comentários, alusões, isto é, uma série heterogênea de enunciados, funcionando sob diferentes registros discursivos, e com uma estabilidade variável. Por se tratar de um enunciado metafórico, "O carnaval acabou" implica múltiplas interpretações: Acabou o quê, como e por quê?

Cabe ao leitor recuperar e interpretar os "não ditos" e estabelecer relações que justifiquem as escolhas linguístico-discursivas do enunciador. Uma possível interpretação do enunciado destacado relaciona os supostos excessos litúrgicos dos antecessores do papa às festas de carnaval, com suas luxuosas fantasias e alegorias características. Assim, o referido enunciado atinge o núcleo do efeito buscado. Ou seja,

produz algo memorável, isto é, um enunciado digno de ser consagrado, antigo de direito, novo de fato. É porque é digno de ser antigo que pode aspirar a um estatuto monumental. Tal enunciado inaugura uma série ilimitada de retomadas, na medida em que se apresenta como o eco de uma série ilimitada de retomadas. Esse tipo de enunciado visa, portanto, produzir, na realidade, aquilo que não passa de uma pretensão enunciativa: apresentando-se como uma sentença já pertencente a um saber compartilhado, ele prescreve, justamente, por isso mesmo, sua retomada ilimitada. (MANGUENEAU, 2006, p.74-5). 
$\mathrm{Na}$ materialidade linguística de "O carnaval acabou", encontram-se as marcas do discurso "outro", que fazem ressurgir o interdiscurso no espaço da memória (COURTINE, 2009). Ou seja, o destacamento se constrói sobre discursos "já ditos", e é isso que faz com que ele se torne um enunciado memorável, isto é, "antigo de direito", "novo de fato". Essa memória, por sua vez, tende a conjurar os acasos do discurso pela reiteração do idêntico, pelo eterno retorno do mesmo (FOUCAULT, 2006). Ela privilegia as formas discursivas da repetição (citação, recitação, comentário), e os mecanismos linguísticos da ligação, do encaixamento e do destacamento, responsáveis, em boa medida, pelos constantes destacamentos desse enunciado na mídia.

Caso semelhante de destacamento midiático pode ser visto no título da reportagem "Homossexuais não devem ser julgados ou marginalizados", publicado no $G 1$, portal de notícias da rede Globo, em 29 de julho de 2013:

Figura 2 - Reportagem 2
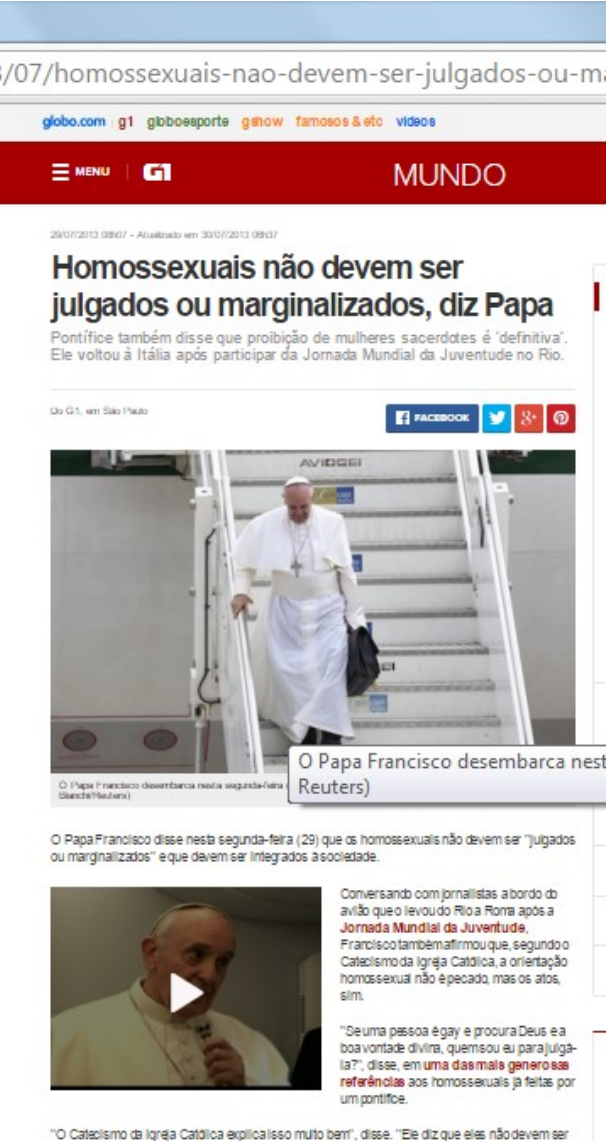

Fonte: Disponível em: <www.g1.globo.com.br>. Acesso em: 29 set. 2013.

$\mathrm{Na}$ entrevista concedida aos jornalistas, durante o voo do Rio de Janeiro a Roma, após a Jornada Mundial da Juventude, em 29 de julho de 2013, ao ser questionado sobre o seu posicionamento em relação aos homossexuais, o papa Francisco teria respondido: “Os gays não devem ser marginalizados, mas integrados à sociedade. Se uma pessoa é gay, busca Deus e tem boa vontade, quem sou eu para julgá-la?”. 
Após a entrevista, a declaração do papa foi convertida na "pequena frase" "Homossexuais não devem ser julgados ou marginalizados" e destacada na mídia. $O$ enunciado destacado deixa claro que o jornalista não somente retirou de um texto maior um "pequeno" enunciado, mas também realizou um trabalho interpretativo sobre o textofonte. Por meio desse trabalho, o jornalista elimina modulações, reforça a autonomia e o caráter lapidar do enunciado, convertendo-o em uma sequência sobreasseverada, que, por sua vez, não apenas resume a declaração do pontífice, mas também a modifica: a substituição do léxico, "gays" por "homossexuais", a junção das palavras "julgados" e "marginalizados", numa mesma oração, bem como o apagamento da expressão "se uma pessoa é gay, busca a Deus e tem boa vontade, quem sou eu para julgá-la?" são responsáveis por essa modificação.

Para o pontífice, a orientação sexual não é um pecado, mas a sua prática sim. " $\mathrm{O}$ problema não é ter essa orientação. O problema é fazer lobby por essa orientação, ou lobbies de pessoas invejosas, lobbies políticos, lobbies maçônicos, tantos lobbies. Esse é o pior problema". (FRANCISCO, 29/07/2013). No entanto, a menos que se faça uma pesquisa, que não está ao alcance de todo mundo, ninguém vai voltar à entrevista em que o papa falou sobre os homossexuais para constatar a autenticidade do enunciado destacado. Do ponto de vista do consumidor das mídias, para os leitores, esse texto de origem não existe.

Fora do texto-fonte, a "pequena frase" "Homossexuais não devem ser julgados ou marginalizados" faz deslizar os sentidos. Ela dialoga com o discurso homofóbico inscrito numa série de acontecimentos, que retratam a forma como os homossexuais, desde sempre, são vistos na sociedade. Dizer que "os homossexuais não devem ser julgados ou marginalizados" implica que há um julgamento sobre eles e a consequência é, dentre outras, a marginalização. $\mathrm{O}$ enunciado em destaque dialoga com o discurso da intolerância e do preconceito, ao mesmo tempo em que busca combatê-los.

Disperso na memória do dizer, o discurso homofóbico se deixa flagrar na interdiscursividade constitutiva do destacamento midiático. O trabalho hermenêutico do enunciador busca silenciar esse discurso, por meio da autoridade do discurso do papa. É como se "discretamente", o jornalista indicasse ao leitor que, para a Igreja, não há nenhuma diferença de tratamento entre homossexuais e heterossexuais, mesmo se os homossexuais não tiverem "boa vontade" e não "buscarem a Deus". A interpretação do enunciador caminha no sentido de construir, para o papa, uma imagem menos conservadora, portanto, mais liberal. Há, nesse sentido, uma tentativa de aproximação da Igreja aos homossexuais e aos simpatizantes, que, por receio de serem marginalizados, não participam das celebrações eucarísticase de outras atividades eclesiásticas.

A autonomização do fragmento recortado frente ao texto de origem pode ir ainda mais longe quando existe uma transformação do enunciado, ou, de um ou outro de seus parâmetros enunciativos, quando ele passa a título e/ou subtítulo de artigo ou de reportagem. É o caso do enunciado publicado pelo jornal online Folha Brasil, no dia 22 de janeiro de 2014: "Não há fogo no inferno, Adão e Eva não são reais". 
Figura 3 - Artigo 1

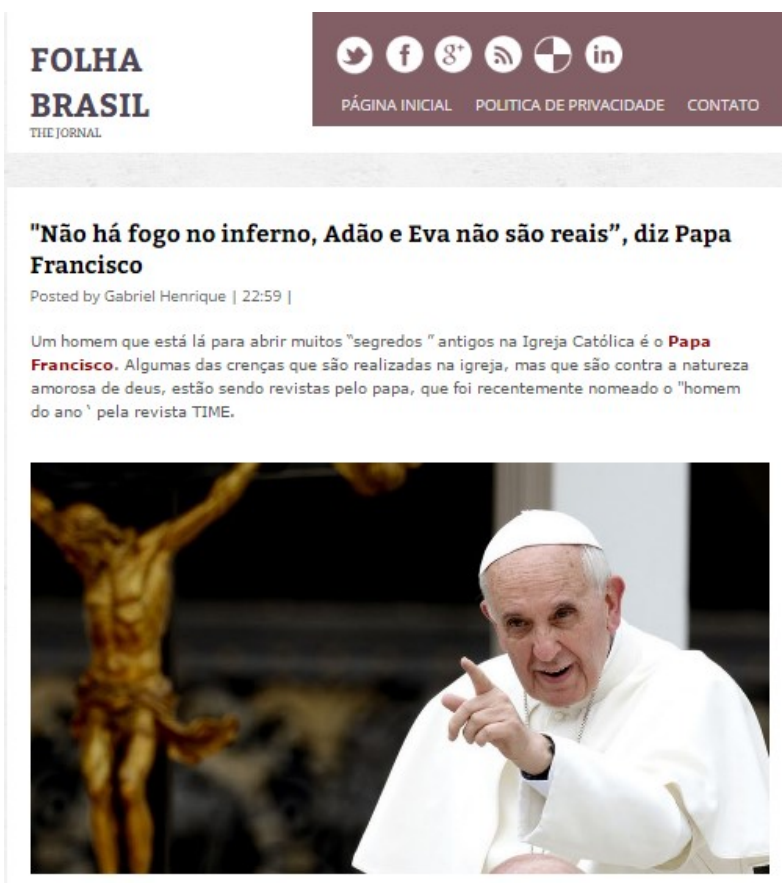

Fonte: Disponível em: <www.folhabrasiloficial.com.br>. Acesso em: 29 jan. 2014.

O texto, que deu origem ao título, diz o seguinte:

\begin{abstract}
A Igreja já não acredita em um inferno literal, onde as pessoas sofrem. Esta doutrina é incompatível com o amor infinito de Deus. Deus não é um juiz, mas um amigo e um amante da humanidade. Deus nos procura não para condenar, mas para abraçar. Como a história de Adão e Eva, nós vemos o inferno como um artifício literário. O inferno é só uma metáfora da alma exilada (ou isolada), que, como todas as almas em última análise, estão unidos no amor com DEUS. (FRANCISCO, 22/01/2014)
\end{abstract}

Também aqui o destacamento "Não há fogo no inferno, Adão e Eva não são reais" não corresponde ao texto original. Sequer encontramos essas duas frases, juntas, numa mesma oração no texto original, conforme atesta o jornalista. No entanto, o referido enunciado é atribuído ao papa, tanto por meio do verbo dizer quanto por meio das aspas. Aliada ao verbo dizer, as aspas autenticam o enunciado destacado, fazendo-o passar por legítimo. Produz-se, com isso, um movimento argumentativo, isto é, o discurso do papa é transformado em uma única frase, generalizante, uma espécie de sentença autonomizada que enuncia um "sentido completo". Assim, o leitor não duvidará da autenticidade do enunciado, mesmo que o pontífice jamais o tenha proferido.

A discursivização do enunciado "Não há fogo no inferno, Adão e Eva não são reais" produz um deslocamento de sentido e engendra retroativamente uma série de implícitos, ocasionando a desautorização de um sentido já formulado. O enunciado destacado retoma a "enunciação original", mas também instaura e sustenta sentidos que intervêm e modificam o "já dito". Nesse caso, a enunciação destacada cria uma nova filiação de sentidos, (re)atualiza o discurso da Igreja e institui uma memória. Trata de rememorar o discurso bíblico sobre a criação da humanidade, inserido no livro de Gênesis: 
03: E ouviram a voz do Senhor Deus, que passeava no jardim pela virada do dia; e esconderam-se Adão e sua mulher Eva da presença do Senhor Deus, entre as árvores do jardim; 09: E chamou o Senhor Deus a Adão, e disse-lhe: Onde estás?” (BÍBLIA, Gênesis, 03, 08-09).

bem como o da punição dos pecados, no Evangelho segundo Lucas:

23: E no inferno ergueu os olhos, estando em tormentos, e viu ao longe Abrão, e Lázaro ao seu lado; 24: E clamando disse: Pai Abrão, tem misericórdia de mim e manda a Lázaro que molhe na água a ponto do seu dedo e me refresque a língua, porque estou atormentado nesta chama. (BÍBLIA, Lucas, 16, 23-24).

Ao rememorar esses discursos, o enunciado "Não há fogo no inferno, Adão e Eva não são reais" busca combatê-los, contrariando, dessa forma, a sabedoria popular cristã, que comumente interpreta o livro do Gênesis em sua literalidade, e imagina o inferno como um lugar propriamente dito, caracterizado por muito sofrimento e constantemente tomado pelo fogo. Assim, a "pequena frase" sobreasseverada coloca o papa diante de uma situação que contraria esse "senso comum".

Se investigarmos no Catecismo da Igreja Católica (1992), em nenhum momento são defendidas essas ideias populares sobre a literatura do Gênesis e o inferno como um lugar. Ao contrário, quando aborda o tema da "Criação" (dos números 279 a 384), o Catecismo utiliza genericamente os termos "homem" e "mulher", ou até mesmo "primeiro homem" (n. 374), "pessoa humana" (n. 362) ou "gênero humano" (n. 360), designando assim uma humanidade genérica, não identificada com uma pessoa concreta e particular. Já quanto ao inferno, o Catecismo o define como "estado de auto exclusão definitiva da comunhão com Deus e com os bem-aventurados” (n. 1033). Nesse sentido, o inferno não é um lugar, mas um "estado". Portanto, as declarações do papa estão em consonância com a doutrina da Igreja; porém, em desacordo com o imaginário popular.

$\mathrm{O}$ enunciado em questão retoma um discurso anterior, mas também aponta para um novo discurso, um novo dizer, produzindo, portanto, a possibilidade do múltiplo e a compreensão da incompletude do discurso que evoca. Isso é possível porque as palavras são portadoras de memória: elas são, como disse Bakhtin (2004), "habitadas" [temporariamente] pelos sentidos e pelos contextos que elas encontraram. O jornalista se apropria desse caráter dialógico dos enunciados e o faz circular, produzindo o efeito de que as ideias do senso comum são a doutrina da Igreja e de que, portanto, o papa Francisco estaria contrariando os ensinamentos da Igreja; quando, na verdade, estava apenas reproduzindo-os.

Para ilustrar, no nosso corpus, a presença do "destacamento fraco", retomamos o excerto publicado no jornal Folha Online, em12 de dezembro de 2014: 


\section{Figura 4 - Artigo 2}

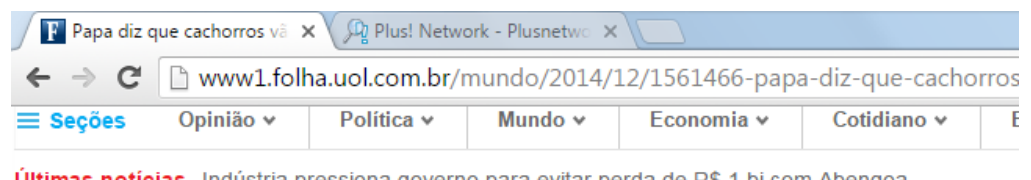

Últimas notícias Indústria pressiona governo para evitar perda de R\$ 1 bi com Abengoa

\section{mundo}

\section{Papa diz que cachorros vão para o céu e cria polêmica com teólogos}

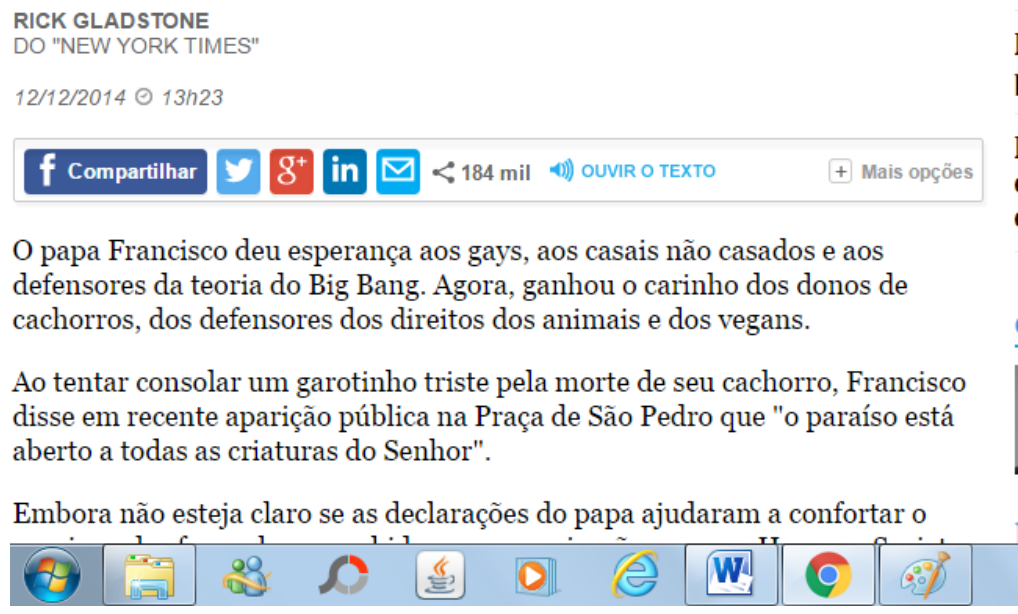

Fonte: Disponível em: <www.folha.uol.com.br>. Acesso em: 12 dez. 2014.

Segundo o jornalista, ao tentar consolar uma criança que estava triste porque perdeu seu cãozinho de estimação, o papa Francisco teria declarado em aparição pública na praça de São Pedro, que "o paraíso está aberto a todas as criaturas do Senhor". No entanto, não foi novamente a declaração do papa que o jornal pôs em circulação. Há, no enunciado destacado, uma transformação significativa tanto do ponto de vista da materialidade linguística quanto da produção discursiva. Ou, dizendo de outro modo, os enunciados, proferido pelo papa e o título do artigo que ilustra a página da Folha, não são os mesmo. Enquanto no enunciado original há uma sentença generalizante marcada tanto pela expressão "o paraíso está aberto" quanto pela expressão "todas as criaturas", o enunciado destacado é bastante específico, "papa diz que cachorros vão para o céu". Essa especificidade do enunciado não apenas altera o enunciado original, mas sugere para o leitor um percurso interpretativo: apenas as almas vão para o céu, logo se os cães vão para o céu é porque eles têm alma. O sentido do texto-fonte é significativamente modificado. No entanto, a sequência sobreasseverada estabelece uma asserção que leva o leitor a crer na veracidade e autenticidade do enunciado em questão.

Destacamento semelhante encontra-se no excerto do jornal A Tribuna, publicado em 01 de setembro de 2015: 


\title{
Figura 5 - Reportagem 3
}

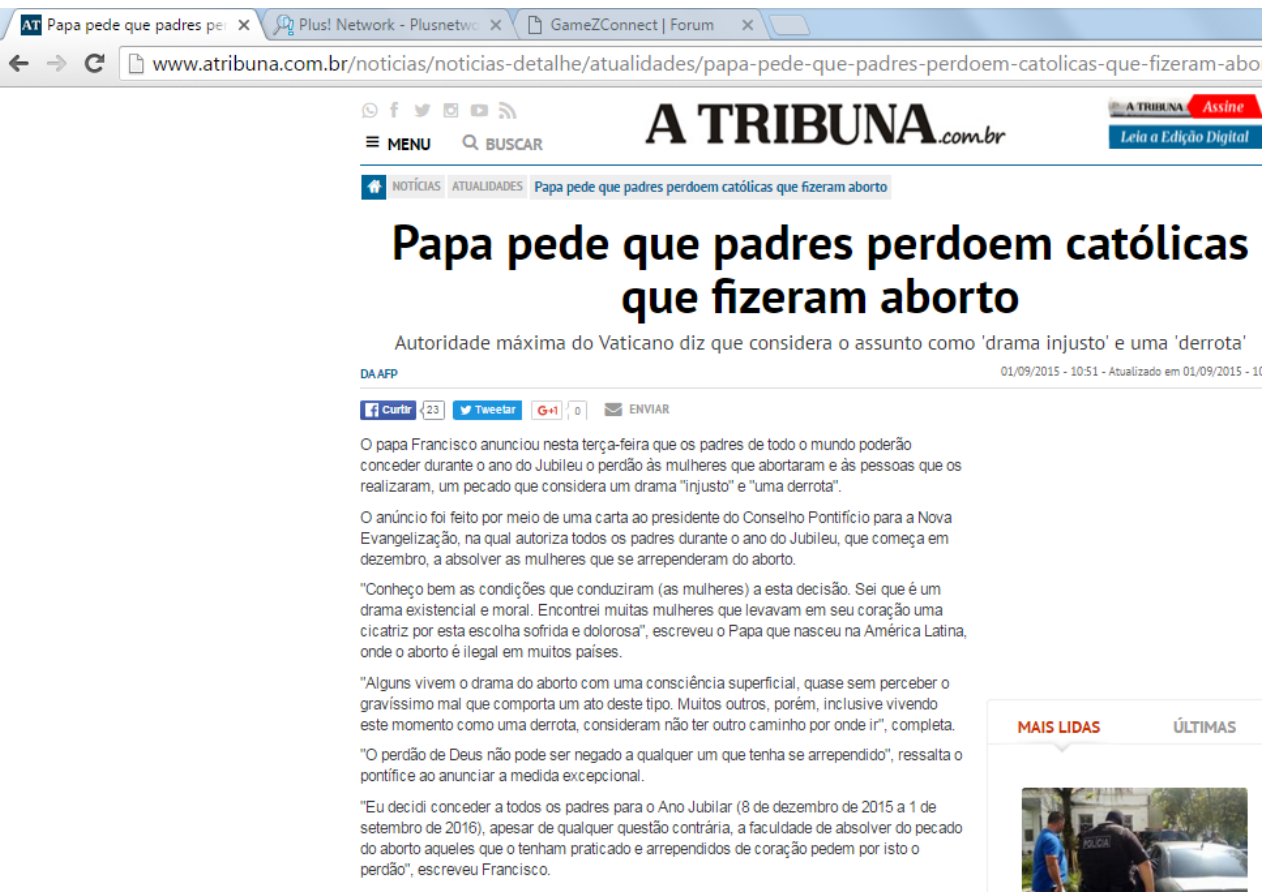

Fonte: Disponível em: <www.atribuna.com.br>. Acesso em: 1 set. 2015.

Se voltarmos à declaração original, verificaremos que há uma alteração de sentido entre o texto da manchete "Papa pede que padres perdoem católicas que fizeram aborto", e o texto-fonte:

\begin{abstract}
Alguns vivem o drama do aborto com uma consciência superficial, quase sem perceber o gravíssimo mal que comporta um ato deste tipo. Muitos outros, porém, inclusive vivem este momento como uma derrota, consideram não ter outro caminho por onde ir. (...). O perdão de Deus não pode ser negado a qualquer um que tenha se arrependido ${ }^{1}$. (FRANCISCO, $01 / 09 / 2015$ )
\end{abstract}

Além da alteração lexical e sintática do enunciado, atribuindo aos padres e não a Deus o poder do perdão, o apagamento da expressão "o perdão de Deus não pode ser negado a qualquer um que tenha se arrependido", na manchete, sugere que os padres perdoem todas as mulheres que praticaram o aborto, mesmo as que não se arrependeram. Não se trata apenas de informar, de destacar o acontecimento enunciativo, tampouco de fazê-lo memorável, mas, sobretudo, de torná-lo legítimo e, consequentemente, de traçar para o leitor um percurso interpretativo.

A sobreasseveração, conforme demonstramos, abre para a saída do enunciado destacável do texto-fonte. Ou seja, abre para a destextualização de fragmentos de textos que não foram formulados como tais, tornando-os, muitas vezes, autônomos frente ao texto de origem. Os enunciados “O carnaval acabou!"; "Homossexuais não devem ser

\footnotetext{
${ }^{1}$ Carta do papa Francisco ao presidente do Conselho Pontifício para a nova Evangelização, durante o Ano
} do Jubileu. 
julgados ou marginalizados"; "Não há fogo no inferno, Adão e Eva não são reais", são bons exemplos desse tipo de destacamento. Destacados pela mídia, eles se tornam autônomos e passam a circular livremente em outros textos. Nesse caso, há uma mudança de estatuto pragmático, isto é, os enunciados destacados deixam de ser um fragmento do texto-fonte e passa a integrar um regime de enunciação específico, que Maingueneau (2014) chama de aforização. A aforização reatualiza a citação, não se trata mais de representar a voz do outro, mas sim de apresentar a "verdade" e/ou a "lei", produzida alhures a partir de uma Fonte Transcendental.

\section{SOBRE A PRODUÇÃO DISCURSIVA DAS AFORIZAÇÕES DESTACADAS NA MÍDIA...}

O conceito de aforização se aplica ao conjunto de enunciados, que Maingueneau (2014) denomina "frases sem texto". Ou seja, frases que não são precedidas ou seguidas de outras frases com as quais estão ligadas por relações de coesão, de modo a formar uma totalidade textual ligada a um "gênero de discurso" ". No entanto, a aforização não fíca totalmente sem contexto. A "contextualidade", segundo o autor, difere segundo se trate uma "aforização primária" (provérbios, slogans, máximas e divisas) e uma "aforização secundária", destacada de um texto. Esse é o caso das "pequenas frases" sobre as quais nos debruçamos, neste estudo.

O não pertencimento a um texto fonte faz com que a "aforização primária" possa ser inscrita em uma infinidade de textos. Seu sentido é uma espécie de instrução sobre as condições de emprego: ele delimita a priori o tipo de contexto nos quais pode ser empregado, mesmo que caiba ao locutor decidir se as condições para seu emprego estão satisfeitas. Em contrapartida, a "aforização secundária" deve ser considerada em dois contextos efetivos: um contexto-fonte e um contexto de recepção. A diferença entre os dois alimenta os comentários, que põem em evidência as "deformações", os "malentendidos", os "deslizamentos de sentido", que o contexto de recepção os fará sofrer.

Vimos anteriormente que a "destextualização" e a "sobreasseveração" contribuem para a saída do enunciado "destacável" do texto de origem, transformando-o, muitas vezes, em aforização. Os enunciados "O carnaval acabou", "Homossexuais não devem ser julgados e marginalizados", "Não há fogo no inferno, Adão e Eva não são reais" são bons exemplos. $\mathrm{O}$ acesso de um fragmento de texto ao estatuto de aforização modifica profundamente seu estatuto pragmático, e, portanto, sua interpretação. Em boa medida, isso acontece porque a "recontextualização" ativa potencialidades semânticas incontroláveis. Dentre as diversas perguntas que mereceriam ser feitas, uma é especialmente necessária: quem é o autor das aforizações destacadas? Por um lado, seu "conteúdo" parece coincidir com a declaração original; por outro, há uma alteração no texto. Seu autor não é mais o pontífice, mas não se pode dizer simplesmente que seja o jornalista, visto que a alteração é uma paráfrase.

No nosso entendimento, o autor passa a ser percebido como um aforizador, (MAINGUENEAU, 2010), isto é, um locutor capaz de transitar de um lado para o outro da diversidade infinita dos gêneros de discursos e dos textos. Ou seja,

\footnotetext{
${ }^{2}$ Maingueneau (2005) mobiliza este termo para atividades como registrar o nascimento, o debate televisivo, o sermão, entre outros.
} 
O aforizador assume um ethos do locutor que está no alto, do indivíduo autorizado, em contato com uma Fonte transcendental. Ele é considerado como aquele que enuncia sua verdade, que prescinde da negociação, que exprime uma totalidade vivida: seja uma doutrina ou uma certa concepção de existência. Por intermédio da aforização veremos coincidir sujeito da enunciação e sujeito no sentido jurídico e moral: alguém que se coloca como responsável, afirmando valores e princípios diante do mundo, se endereçando a uma comunidade para além dos locutores empíricos que são seus destinatários. (MAINGUENEAU, 2010, p.14-15).

O aforizador não é o locutor, o suporte da enunciação, mas uma consequência do destacamento. Não se trata apenas de uma instância enunciativa, mas de uma instância "hiperenunciativa" em contato com uma Fonte Transcendental. Assim, quando se extrai um fragmento de um texto para fazer dele uma aforização, um título de uma matéria na imprensa, por exemplo, converte-se ipso facto seu locutor original em aforizador. A aforização não se apresenta como um fragmento de texto, mas como um enunciado autossuficiente, situado ao mesmo tempo "no" texto em que está inserido e "fora" de qualquer texto.

Passamos a análise de mais um excerto: "Não existe um Deus católico, mas um Deus", publicado no jornal Brasil Estadão, em 02 de outubro de 2013:

Figura 6 - Reportagem 4

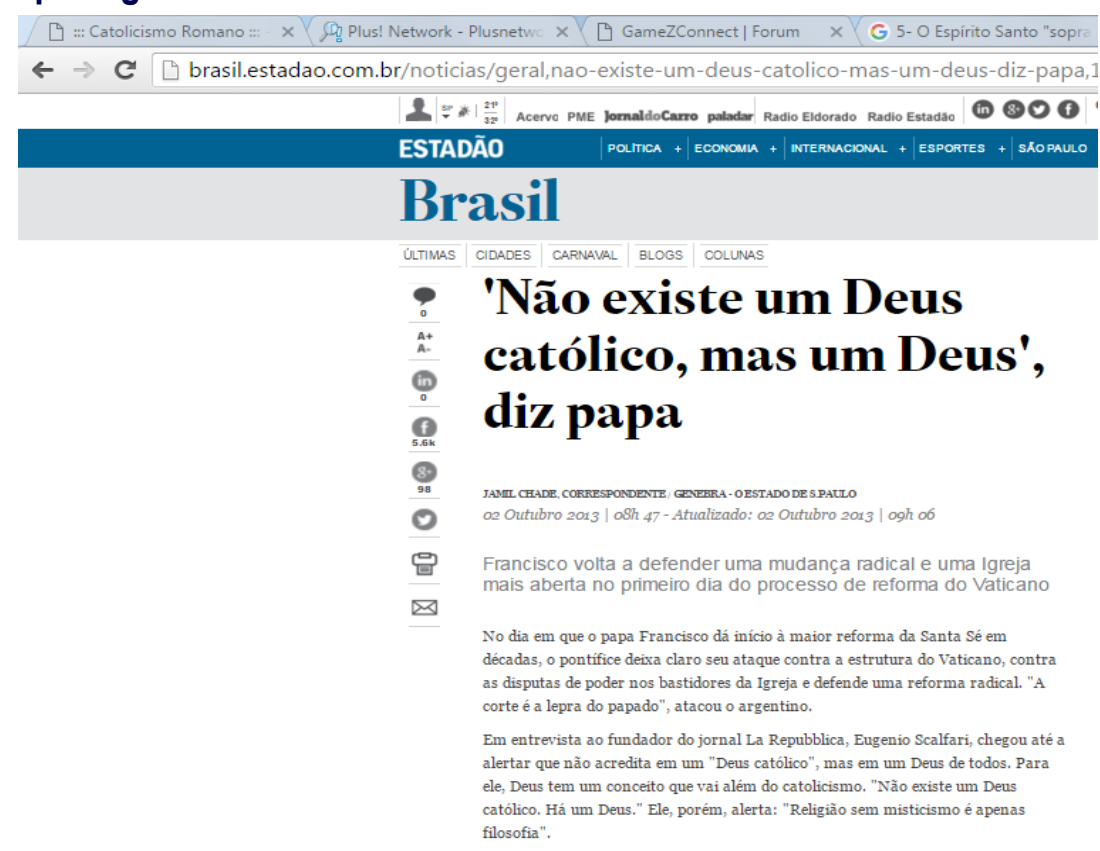

Fonte: Disponível em: < www.brasil.estadão.com.br >. Acesso em: 2 out. 2013.

Ao realizar o destacamento midiático acima, o enunciador não está dialogando nem com o locutor da fala destacada nem com o destinatário (o leitor). Sua fala monologalmente construída se inscreve como a fala autorizada, como se proviesse de uma Fonte Transcendental. Em outros termos, ao destacar e modificar parte da declaração do papa, o aforizador recorre a um Thesaurus, isto é, a um conjunto de saberes de conhecimento público, para validar a sua enunciação. A extração do texto base não se dá 
por acaso, ela remete a um discurso "já dito", que o enunciador julga ser de conhecimento público. Nesse caso, o saber partilhado entre os cristãos é de que "Deus é católico". A aforização não só dialoga com esse saber, mas também o contesta, colocando em destaque que, para o pontífice, portanto, para a Igreja, Deus não tem religião.

No momento em que o jornal Estadão Brasil insere monologalmente a aforização "Não existe um Deus católico, mas um Deus", atribuída ao papa Francisco, o leitor é levado a atribuir a esse enunciado um sentido que extrapola o da enunciação original. As possíveis interpretações produzidas pelos leitores não são da mesma ordem das que acompanham os textos literários, filosóficos, ou religiosos, por exemplo. A interpretação assume a equação: "Dizendo $\mathrm{X}$, o locutor implica $\mathrm{Y}$ ", onde "Y" se constitui num enunciado genérico de valor deôntico: Deus existe; Deus (não) tem uma religião; Deus (não) é católico; etc.

A materialidade linguística do enunciado aparece atravessada por uma divisão discursiva entre dois espaços:

o da manipulação de significações estabilizadas, normalizadas por uma higiene pedagógica do pensamento, e o de transformações do sentido, escapando a qualquer norma estabelecida a priori, de um trabalho de sentido sobre o sentido, tomados no relançar indefinido das interpretações. (PÊCHEUX, 2006, p. 51)

Dessa forma, a aforização "Não existe um Deus católico, mas um Deus" coloca necessariamente em jogo, através do advérbio de negação e do verbo "existir", o "discurso-outro" como espaço imaginário desse enunciado. Esse "discurso-outro" sugere aos leitores os sentidos do enunciado.

Soma-se ao exemplo ilustrado, a aforização "Cristãos não devem procriar como coelhos", publicada no site da revista Veja, em 09 de janeiro de 2015:

\section{Figura 7 - Reportagem 5}

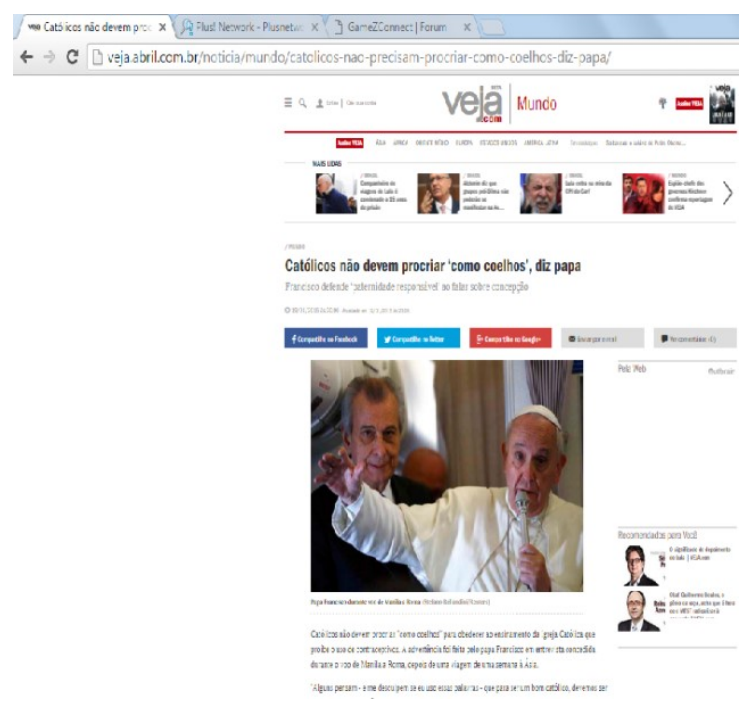

Fonte: Disponível em: <www.veja.abril.com.br>. Acesso em: 19 jan. 2015. 
$\mathrm{Na}$ matéria acima, a aforização faz alusão ao discurso bíblico, sobre o início da humanidade: "Deus abençoou Noé e seus filhos. Sede fecundos, disse-lhe ele, multiplicaivos e enchei a terra". (BÍBLIA, Gênesis, 09, 01), ao mesmo tempo em que o refuta.

Ao comparar os cristãos aos coelhos, a referida aforização coloca em questão o crescimento "desenfreado" da população mundial. É como se discretamente o enunciador indicasse ao leitor que o papa Francisco não concorda com o discurso bíblico que alicerça a aforização. A enunciação original "algumas pessoas pensam - me desculpem a expressão aqui - que para ser um bom católico precisam ser como coelhos. Não. Paternidade tem a ver com responsabilidade. Isto é claro." (FRANCISCO, 19/01/2015), novamente é modulada, ou seja, sofre as coerções do trabalho hermenêutico do jornalista que, ao noticiar referida declaração, não só busca chamar a atenção dos leitores para a falta de planejamento familiar, mas também colabora no sentido de criar uma imagem menos tradicional para o pontífice. Trata-se de sugerir uma mudança de posicionamento na Igreja, que não vê com bons olhos o crescimento familiar sem planejamento. A aforização (re)direciona os sentidos e, com isso, coloca o enunciador numa situação discursiva bastante confortável, uma vez que o aporte ao aforizador o desresponsabiliza por aquilo que diz.

Efeito de sentido semelhante pode ser encontrado no excerto publicado no $G 1$, portal de notícias da rede Globo, em 05 de outubro de 2005:

\section{Figura 8 - Reportagem 6}
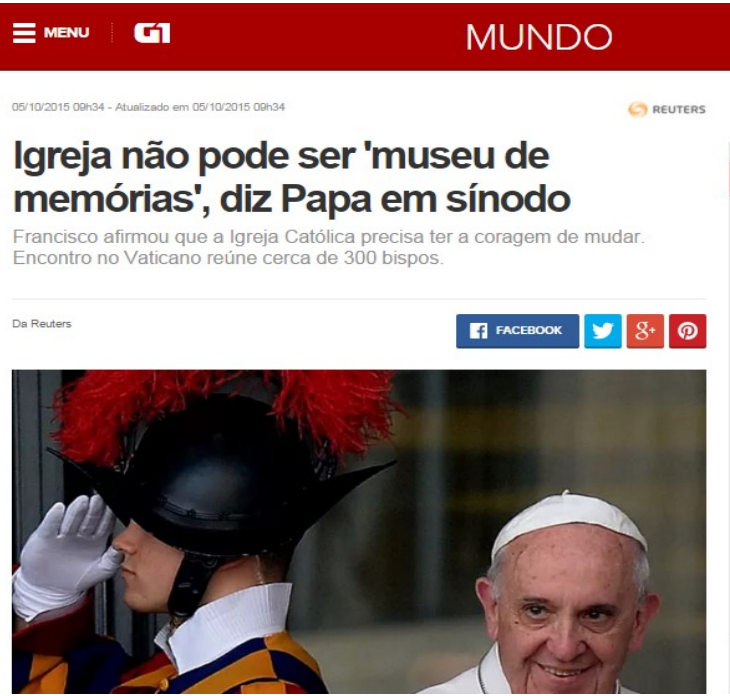

Fonte: Disponível em: <www.g1.globo.com.br>. Acesso em: 5 out. 2015.

Ao voltarmos à enunciação original "A Igreja não deve ser um tacanho museu de memórias, mas precisa ter a coragem de mudar, se for isso o que Deus quiser", (FRANCISCO, 02/10/2015), verificamos que o contexto de produção e de recepção da aforização destacada não é o mesmo. A substituição lexical do verbo dever, na formulação original, pelo verbo poder, na aforização destacada, bem como o apagamento da expressão "mas precisa ter a coragem de mudar, se for isso o que Deus quiser", são, em grande medida, responsáveis por essa alteração de sentidos. Dizer que a "Igreja não pode ser um museu de memórias", não é o mesmo que dizer que a "Igreja não deve 
ser um tacanho museu de memórias". Há aí uma mudança significativa de sentido: enquanto na aforização destacada a Igreja não pode exercer a função de museu de memórias, na enunciação original, do ponto de vista linguístico e discursivo, essa proibição não existe. O pontífice apenas fala sobre uma possível mudança na Igreja, levando em consideração a vontade de Deus. No entanto, a aforização destacada sugere ao leitor a interpretação de que o papa não concorda com o conservadorismo da Igreja.

Para encerrar a análise, mobilizamos o excerto publicado no jornal Extra, no dia 18 de fevereiro de 2016:

\title{
Figura 9 - Artigo 3
}

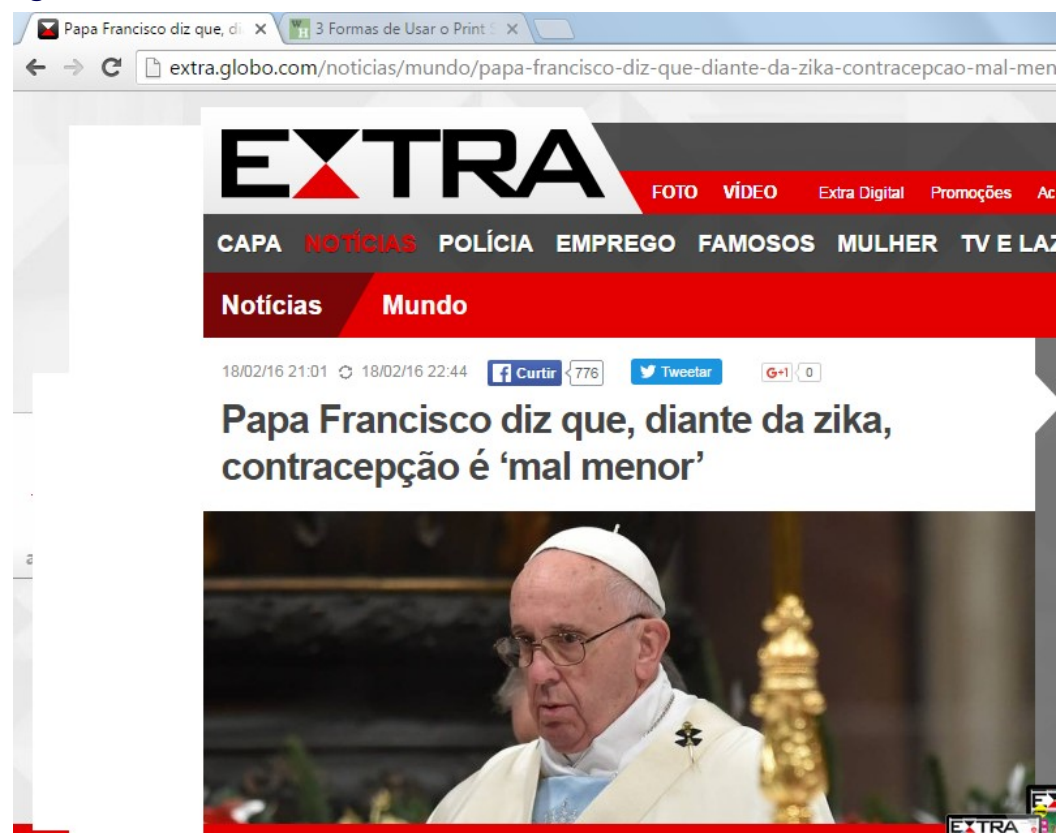

Fonte: Disponível em: <www.extra.globo.com>. Acesso em: 18 fev. 2016.

Em declaração a bordo do avião que o conduziu do México à Itália, no dia 18 de fevereiro, o papa Francisco, ao ser questionado sobre a possibilidade de mulheres, angustiadas pela ameaça do $Z i k a^{3}$, evitarem a gravidez, respondeu:

\begin{abstract}
O aborto não é um mal menor. É um crime. É descartar um para salvar o outro. Mas evitar a gravidez é. Paulo VI, em uma situação difícil, na África, permitiu às religiosas o uso de anticoncepcionais em casos de (iminente) violência. Não confunda o mal de evitar a gravidez, sozinho, com o aborto. Evitar a gravidez não é um mal absoluto, e, em certos casos, como no que mencionei do Beato Paulo VI, era claro. (FRANCISCO, 18/02/2016)
\end{abstract}

\footnotetext{
${ }^{3}$ O Zika é uma doença viral aguda, transmitida principalmente pelo mosquito Aedes aegypti. Os principais sintomas são dor de cabeça, febre baixa, dores leves nas articulações, manchas vermelhas na pele, coceira e vermelhidão nos olhos. Outros sintomas menos frequentes são inchaço no corpo, dor de garganta, tosse e vômitos. No geral, a evolução da doença é benigna e os sintomas desaparecem espontaneamente após 3 a 7 dias. No entanto, a dor nas articulações pode persistir por aproximadamente um mês. Formas graves e atípicas são raras, mas quando ocorrem podem, excepcionalmente, evoluir para óbito, como identificado no mês de novembro de 2015, pela primeira vez na história. (MINISTÉRIO DA SAÚDE, 2016). $<\mathrm{http}: / /$ combateaedes.saude.gov.br/pt/tira-duvidas $>$. Acesso em 24 out. 2016.
} 
Após a declaração, a mídia colocou em circulação o enunciado "Papa Francisco diz que, diante de Zika, contracepção é "um mal menor”. Um único elemento do discurso do pontífice foi "destextualizado" e passou a integrar o título da matéria, sugerindo que, diante de Zika, o papa Francisco abre uma exceção e libera o uso de métodos contraceptivos. No enunciado original, o papa não diz que a contracepção é "um mal menor", mas enfatiza que, em casos extremos, como nos casos de violência sexual, e/ou nos que coloquem em risco a saúde da mãe e/ou do bebê, "evitar a gravidez é". Sem, no entanto, mencionar a maneira de evitá-la. Ao falar sobre o uso de anticoncepcionais, o pontífice lembra que, em outro momento da história, o papa Paulo VI concedeu permissão às religiosas para usá-los, devido à iminência de violência sexual. Portanto, a declaração de Francisco não é uma excepcionalidade na Igreja.

Mesmo não sendo excepcional, a referida declaração provocou muitos comentários, tais como: "Papa Francisco admite o uso de contraceptivos contra o vírus da Zika",; "Papa fala de possibilidade de uso de contraceptivos por causa de Zika" ; Por causa de Zika e microcefalia, papa abre exceção para uso de contraceptivos";"; "Para combater Zika, papa admite uso de anticoncepcionais ${ }^{7}$ ", entre outros. Foram tantos os comentários que o papa Francisco voltou a falar sobre o assunto. Em suas novas declarações, tornou a enfatizar que, em ocasiões extremas, o uso de métodos contraceptivos é uma prática aceitável.

Outro fator importante na produção de sentidos desse destacamento midiático diz respeito ao fato de ele vir associado à fotografia do papa, que, por sua vez, não condiz com o contexto original de produção da enunciação. Como mencionamos, o papa fez essa declaração a bordo do avião, no entanto, a fotografia apresenta o papa em outra cena enunciativa: o plano de fundo, as vestes e os objetos litúrgicos levam à interpretação de que o papa a teria pronunciado na Igreja. Para nós, essa mudança de cena tem a ver com as estratégias interpretativas desenhadas pelo enunciador no sentido de autenticar a enunciação destacada, e, ao mesmo tempo, indicar para o leitor que o papa fala não somente em nome da Igreja, mas para a Igreja.

No entendimento de Maingueneau, a associação frequente entre aforizações e rostos se explica porque o rosto possui características notáveis, tais como:

1 - é a única parte do corpo que, de maneira superficial, permite identificar um indivíduo como distinto de outros;

2 - é, no imaginário profundo, a sede do pensamento e de valores transcendentais;

3 - é nele que se encontra a boca, fonte da fala e, portanto, da aforização. (MAINGUENEAU, 2014, p.46)

Isso explica a constante recorrência de fotografias do rosto do papa Francisco associadas às aforizações destacadas na/pela mídia. Em sua grande maioria, tais fotografias, conforme atestam os exemplos mobilizados, não enfocam apenas o rosto do papa, mas também as suas vestes, a arte sacra e os objetos litúrgicos, que juntos evocam

\footnotetext{
${ }^{4}$ Destaque enunciativo publicado no site http://www1.folha.uol.com.br/, 18/02/2016;

${ }^{5}$ Destaque enunciativo publicado no site http://g1.globo.com 18/02/2016;

${ }^{6}$ Destaque enunciativo publicado no site http://ultimosegundo.ig.com.br, 18/02/2016;

${ }^{7}$ Destaque enunciativo publicado no site http://agenciabrasil.ebc.com.br 19/02/2016;
} 
a imagem da Igreja. Assim, as aforizações não falam apenas em nome do papa, mas, sobretudo, em nome da Igreja, que é significada de forma menos conservadora, com o pontificado de Francisco.

Soma-se aos exemplos citados uma centena de enunciados destacados das declarações do papa Francisco, na mídia, que corroboram essa leitura, tais como: "Papa Francisco diz que batizaria até marcianos" " "O mundo digital pode ser um ambiente rico em humanidade, é uma rede não de cabos, mas de pessoas", "Divorciados que voltam a se casar e seguem fazendo parte da Igreja não devem ser tratados como excomungados ${ }^{10 ",}$ entre outros. No entanto, não julgamos necessário trazê-los à discussão, visto que os apresentados são suficientes para afirmarmos que, ao destacar e/ou aforizar o discurso do papa, o enunciador não apenas informa o acontecimento enunciativo, mas, sobretudo, propõe para o leitor um percurso interpretativo que (re)atualiza esse acontecimento. Assim pensada, a mídia vai se patenteando muito mais como uma instância de circulação de sentidos e interpretações do que propriamente de circulação dos fatos.

\section{CONSIDERAÇÕES FINAIS}

No decorrer deste estudo, buscamos compreender o funcionamento discursivo dos destacamentos midiáticos extraídos dos discursos do papa Francisco desde o início do seu pontificado, em março de 2013, até os dias atuais. À luz dos conceitos de destacabilidade, sobreasseveração e aforização (MAINGUENEAU, 2006; 2010; 2014), foi possível constatar que os destaques efetuados pela mídia, colocando o locutor original ora como sobreasseverador, ora como aforizador, não apenas convida o leitor a realizar uma interpretação para os acontecimentos enunciativos destacados, mas propõe para esse leitor um percurso interpretativo.

No momento em que a mídia destaca as aforizações do discurso do papa Francisco, coloca em questão os pronunciamentos do pontífice em relação à doutrina da Igreja, e, por consequência, em relação à sabedoria popular cristã. Nessa circunstância, o leitor é interpelado a se identificar com esse sentido orientado e a atribuir a esses gestos interpretativos efeitos que extrapolam o sentido primeiro. Trata-se de uma verdadeira atitude hermenêutica que faz com que os leitores mobilizem um conjunto de saberes interdiscursivos para interpretar os enunciados destacados, procurando reconstruir o percurso interpretativo desenhado pela mídia. Desse percurso, abrem-se as brechas interpretativas para os leitores construírem e repassarem em suas práticas sociais.

A matriz de orientação deôntico-interpretativa de sentido assume a equação: "Dizendo X, o locutor implica Y", em que o "Y" se constitui em um enunciado genérico de valor deôntico. Assim, as aforizações "Homossexuais não devem ser julgados e marginalizados", "Não há fogo no inferno, Adão e Eva não são reais!", "Não existe um Deus católico, mas um Deus", "Cristãos não devem procriar como coelhos"; "Igreja não pode ser museu de memórias", sugerem ao leitor a construção de uma imagem do papa Francisco como revolucionário e heterodoxo, que não apenas diz o que

\footnotetext{
${ }^{8}$ Destaque enunciativo publicado no site http://www.noticiais.uol.com.br, em 12/05/2014;

${ }^{9}$ Destaque enunciativo publicado no site http://www.noticias.terra.com.br, em 10/02/2015;

${ }^{10}$ Destaque enunciativo publicado no site http://www.correiobrasilense.com.br, em 05/08/2015.
} 
pensa, mas impõe, devido à posição de liderança que ocupa na Igreja, novos modos de ver e agir na sociedade.

A forma negativa, em geral, polifônica das estruturas sintáticas, o valor impositivo dos verbos (dever; poder; existir), bem como a conjugação no presente do indicativo (não é um presente dêitico, mas atemporal) revelam o caráter deôntico dos enunciados destacados, que, por sua vez, dialogam com o discurso produzido alhures, respectivamente: A sociedade julga e marginaliza os homossexuais; Há fogo no inferno; Adão e Eva deram origem à humanidade; Deus é cristão; Os cristãos acreditam que devem ter muitos filhos; a Igreja é conservadora. Trata-se de discursos inscritos na sabedoria popular cristã, que são chamados à discussão na materialidade linguística das aforizações destacadas.

Vale lembrar que o discurso religioso é um lugar de memória. Na religião, a memória funciona como um poder. Ela funda uma possibilidade de se expressar, abre um direito à fala, possui, até mesmo, um valor performativo de proposição eficaz. Assim, o discurso religioso é recoberto com o peso da tradição, que o inscreve numa série de sentidos e de razão, que ancora a volatilidade das palavras com o peso da lembrança. De fato, a memória religiosa se inscreve nas aforizações destacadas do discurso do papa, fazendo com que alguns discursos sejam relembrados, repetidos e retomados. Encontramo-nos, aqui, com Foucault (2006), para quem

\begin{abstract}
a repetição indefinida dos comentários é trabalhada do interior pelo sonho de uma repetição disfarçada: em seu horizonte não há talvez nada além daquilo que já havia em seu ponto de partida, a simples recitação. O comentário conjura o acaso do discurso fazendo-lhe sua parte: permite-lhe dizer algo além do texto mesmo, mas com a condição de que o texto mesmo seja dito e de certo modo realizado. A multiplicidade aberta e o acaso são transferidos, pelo princípio do comentário, daquilo que arriscaria de ser dito, para o número, a forma, a máscara, a circunstância da repetição. O novo não esta no que é dito, mas no acontecimento de sua volta. (FOUCAULT, 2006 p. 25-6)
\end{abstract}

É assim que surgem novos enunciados e/ou que enunciados "antigos" são (re)atualizados, nas aforizações destacadas do discurso do papa. Os efeitos de sentido dessas aforizações não dependem dos atos, escolhas ou decisões do enunciador, mas exatamente de uma configuração determinada de saber no interdiscurso, na instância do que se denomina a exterioridade do enunciável (MAINGUENEAU, 2005). Em outros termos, os objetos de discurso que se inscrevem nas aforizações destacadas são elaborados na instância do interdiscurso (exterior constitutivo), e são retomados no intradiscurso (PÊCHEUX, 2009), muitas vezes, na forma de discursos transversos, responsáveis pelo estabelecimento das relações de sentido.

Isto posto, compreendemos que a análise empreendida, embora pouco numerosa e não exaustiva de um grande corolário a ser ainda pesquisado, fornece subsídios para afirmarmos que além de recortar e fazer circular enunciados, a mídia é também uma poderosa máquina de (trans)formar enunciados e produzir simulacros, na medida em que põe em circulação apenas os enunciados destacados e aforizações que afrontam um ensinamento da Igreja, segundo o senso comum dos cristãos. A nosso ver, o próprio processo de destacar e aforizar os enunciados proferidos pelo papa se constitui em um simulacro, na medida em que apaga aquilo que poderia colocar sob suspeita a interpretação que faz do discurso recortado. 
BAKHTIN, M; VOLOCHINOV, V. N. Marxismo e filosofia da linguagem. Trad. Michel Lahud; Yara Frateschi Vieira. São Paulo: Hucitec, 2004.

BÍBLIA. Português. A Bíblia de Jerusalém. Nova edição rev. e ampl. São Paulo: Paulus, 2002.

CATECISMO DA IGREJA CATÓLICA. São Paulo: Loyola, 2000. p. 657.

COURTINE, J.-J. Análise do discurso político: o discurso comunista endereçado aos cristãos. [1983] Trad. Cristina de Campos Velho Birck et al. São Paulo-SP: EduFScar, 2009.

FOUCAUlT, M. A ordem do discurso. Trad. Laura Fraga de Almeida Sampaio. São Paulo: Loyola, 2006.

KRIEG-PLANQUE, A; OLLIVIER-YANIV, C. Poser les petites phrases comme objet d'étude. Langages, Paris, n. 168, p.17-22, juin 2011.

MAINGUENEAU, D. Frases sem textos. Trad. Sírio Possenti et al. São Paulo: Parábola Editorial, 2014. Cenas da Enunciação.Trad. Sírio Possenti et al. Curitiba-PR: Criar, 2006. Gênese dos discursos [1984]. Trad. Sírio Possenti. São Paulo: Criar Edições, 2005. Doze conceitos em Análise do Discurso. Trad. Adail Sobral et al. São Paulo: Parábola, 2010.

PÊCHEUX, M. O discurso: estrutura ou acontecimento? Trad. Eni Pulcinelli Orlandi. Campinas: Pontes, 2006.

Pontes, 2009

Semântica e discurso: uma crítica à afirmação do óbvio.Trad. Eni Pulcinelli Orlandi. Campinas:

\section{DADOS DE CORPUS}

A TRIBUNA. Papa pede que padres perdoem católicas que fizeram aborto. Matéria publicada em 01/09/2015. Disponível em <www.atribuna.com.br> Acesso em mar. 2016.

CORREIO BRASILIENSE. Papa: Divorciados que voltam a se casar e seguem fazendo parte da Igreja não devem ser tratados como excomungados. Matéria publicada em 05/08/2015. Disponível em $<w w w . c o r r e i o b r a s i l e n s e . c o m . b r>$ Acesso em mar. 2016.

ESTADÃO BRASIL. Não existe um Deus católico, mas um Deus, diz papa. Matéria publicada em 02/10/2013. Disponível em <www.brasil.estadão.com.br> Acesso em março de 2016.

EXTRA. Papa Francisco diz que, diante de Zika, usar anticoncepcionais é "um mal menor.

Matéria publicada em 18/02/2016. Disponível em <www.extra.globo.com.br> Acesso em mar. 2016.

FOLHA ONLINE. O carnaval acabou, diz papa Francisco ao recusar a capa usada por Bento 16. Matéria publicada em 16/03/2013. Disponível em <www.folha.uol.com.br> Acesso em mar. 2016.

FOLHA BRASIL. Não há fogo no inferno, Adão e Eva não são reais, diz o papa Francisco. Matéria publicada em 22/01/2014. Disponível em <www.brasil.estadão.com.br> Acesso em mar. 2016.

FOLHA. Papa diz que cachorros vão para o céu e cria polêmica com teólogos. Matéria publicada em 12/12/2014. Disponível em <www.folhauol.com.br> Acesso em mar. 2016.

G1. Homossexuais não devem ser julgados ou marginalizados, diz papa. Matériapublicada em 29/07/2013. Disponível em <www.g1.globo.com.br> Acesso em mar. 2016.

G1. Igreja não pode ser museu de memórias, diz o papa em Sínodo. Matéria publicada em 05/10/2015. Disponível em <www.g1.globo.com.br> Acesso em mar. 2016.

VEJA. Católicos não devem procriar como coelhos, diz papa. Matéria publicada em 19/01/2015.

Disponível em <www.veja.abril.com.br> Acesso em mar. 2016.

SOUZA, Marilena Inácio de. Dos discursos do papa Francisco à produção e circulação de pequenas frases: a construção do papa heterodoxo. Linguagem em (Dis)curso - LemD, Tubarão, SC, v. 16, n. 3, p. 465-487, set./dez. 2016. 
Recebido em 30/05/16. Aprovado em: 18/10/16.

Title: From Pope Francis'speeches to the production and circulation of small phrases: the construction of the heterodox Pope

Author: Marilena Inácio de Souza

Abstract: The recent development of a media configuration totally new, which it is directly associated with the printed media, radio, television and the Internet, has significantly increased the posting and circulation of small sentences. In trying to understand the linguistic and discursive functioning of this phenomenon, we analyzed a set of statements taken from the Pope Francis' speeches and detached in the media. The goal is to check the extent to which, the enunciator's hermeneutic work interfere in the interpretation of the quoted text, providing the reader a kind of interpretive route. Thereunto, an analysis was carried out based on Discourse Analysis, more specifically the works by Dominique Maingueneau (2006; 2010; 2014). The analysis performed allows to say that the posted statements potentiate the (re)production and circulation of simulations about the Pope's speech. There is, therefore, the construction of the image of an heterodox Pope.

Keywords: Detachment media. Small sentence. Meaning effect.

Título: De los discursos del Papa Francisco hasta la producción y circulación de pequeñas frases: la construcción del Papa heterodoxo

Autor: Marilena Inácio de Souza

Resumen: El desarrollo reciente de una configuración mediática totalmente nueva, que asocia directamente la media impresa, la radio, la televisión y el internet, he permitido aumentar significativamente el destacamento y la circulación de pequeñas frases. Para intentar comprender el funcionamiento lingüístico y discursivo de ese fenómeno, analizamos un conjunto de enunciados extraidos de los discursos del papa Francisco y destacados en la media. La meta es verificar en qué medida el trabajo hermenéutico del enunciador interfiere en la interpretación del texto citado, proporcionar al lector una especie de ruta interpretativa. Para ello, movilizamos varios conceptos del Análisis del Discurso francesaespecialmente los conceptos de lo que es destacable, sobreaseveración y aforización, desarrollados por Maingueneau (2006; 2010; 2014). El análisis emprendido autoriza a decir que los enunciados destacados potencializan la (re)producción y circulación de simulacros sobre el discurso del papa. Se tiene por consecuencia la construcción de la imagen de un papa heterodoxo.

Palabras-clave: Destacamento mediático. Pequeña frase. Efecto de sentido.

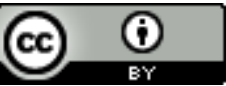

Este texto está licenciado com uma Licença Creative Commons Atribuição 4.0 Internacional. 